\title{
ДУХОВНО-НРАВСТВЕННЫЕ ИСКАНИЯ
}

\author{
А.Р. Децюк
}

\section{ТРАНСФОРМАЦИЯ ОБРАЗА РОДИНЫ - КАК НЕОТЬЕМЛЕМОГО ЭЛЕМЕНТА НАЦИОНАЛЬНОЙ ИДЕИ РОССИИ}

\begin{abstract}
Аннотация. На протяжении всей истории Государства Российского образ Родины менялся в понимании населения страны. Но стоит отметить, что менялась только внешняя сторона понимания, не затрагивая основу представления о Родине. Каждая историческая эпоха накладывала свой отпечаток на эти представления. Особая роль принадлежит внешнеполитическому аспекту бытования страны. Россия в каждом столетии с момента формирования государства, вела войны. В нашей истории были эпизоды, когда стоял вопрос о самом существовании государства, сохранении национальной самобытности, сохранении национальной культуры. Таким образом, с момента формирования русской государственности, формируется образ Родины. Использование ретроспективного метода, позволило нам проследить основные вехи трансформации образа Родина на протяжении всей истории нашего государства. Сравнительно-исторический метод дал возможность доказать, что существует два пласта восприятия образа Родины, связанные, прежде всего, с ее защиты. Защита Родины с оружием в руках и защите культуры. Сегодня мы не можем или не хотим понять, что наша национальная идея - это сохранение культуры. Стремление к сохранению культуры органически заложено в каждом народе. Первый пласт восприятия образа Родины в рамках защиты государства отходит на второй план. Безусловно, на первом плане пласт сохранения своей самобытности. А значит и сохранение государства.
\end{abstract}

Ключевые слова: трансформация, Родина, история, национальная идея, образ, культура, защита, восприятие, пласт, духовность.

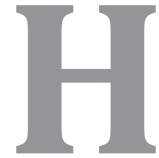
а протяжении всей истории Государства Российского образ Родины менялся в понимании населения страны. Но изменения эти носили скорее «косметический» характер, чем глубинный.

Еще до принятия христианства на Руси идет процесс формирования образа Родины у славян. В числе обычаев славян есть право матери умертвить дочь, если семейство разрослось, но: «... обязывалась хранить жизнь сына, рожденного служить Отечеству» ${ }^{1}$ Образ Родины, Отечества, обязанность мужчины защищать Родину. Карамзин

\footnotetext{
${ }^{1}$ Карамзин Н.М. История Государства Российского. В 3-х тт. Том I. Главы II, III, Х. Тула: Приокское изд., 1990. С. 76, 106, 183.
}

понимает Отечество, с позиций своего времени. Как это понимали славяне, Карамзин знать не мог. Однако опора на источники и их анализ, помогут приблизиться к более объективному и истинному представлению. Также в этот период (до крещения) можно говорить о прославлении оружия. Таким образом, с момента формирования государства на Руси, происходит формирования образа Родины. И прежде всего это понимание связано с защитой государства. Возможность отстаивать его интересы.

В источнике XIII века читаем: «0, светло светлая и прекрасно украшенная, земля Русская»².

${ }^{2}$ Памятники литературы Древней Руси. XIII век / Пер. Л. А. Лихачева. М., 1981. С. 130-131. 


\section{Педагогика и просвещение 3(11) • 2013}

Образ Родины позиционируется с Русью православной: «Всем ты преисполнена, земля Русская, о правоверная вера христианская» ${ }^{1}$. После принятия христианства на Руси в 988 г., в православной его форме произошло серьёзнейшее изменение в восприятии Родина. Отныне и до сегодняшнего дня наше государство является опорой православия в мире. Русь становится Русью правоверной. Защита Родины теперь это защита веры, дело богоугодное.

XII - начало XIII вв. это период раздробленности на Руси. Зададимся вопросом. Каков образ Родины в этот период? «Удельное» понимание, в рамках княжества? Или понимание более масштабное, в рамках всего государства? Или понимание «малой» и «большой» Родины? В «Слове о полку Игореве» постоянно фигурируют тенденции к единству, к сплочению, тема русской земли и её судьбы ${ }^{2}$. Государство, разъединенное в силу закономерных исторических обстоятельств, всё-таки осознает свое культурное и духовное единство. Еще в 1097 году на Любеческом съезде князей прозвучали слова: «почто губим Рускую землю», а половцы «землю нашю несуть роздно». Несмотря на то, что съезд, по сути, юридически оформил политическую раздробленность Руси, идеи единства для отпора врагу были высказаны. Только в тот исторический период единства быть не могло. А потом будет тяжелейший период ордынского ига, который продлится более 200 лет. Удельное мышление, независимость князей привели к тому, что Русь оказалась зависимой от Орды. Но уже в 1240 и в 1242 году юный князь Александр Ярославич, позже прозванный Невский одержит убедительные победы над шведами и немцами. В результате битвы на Чудском озере Ливонский орден фактически был уничтожен. Государство оправляется от тяжелейшего монголо-татарского нашествия, но до решающих побед еще далеко. В этот период времени Русь, предстает страдаюей Русью матушкой, изнывающей под гнётом чужеземцев.

8 сентября 1380 года на поле Куликовом русские дружины под знаменами [или хоругвями, такое название можно найти в летописях] с изображениями святых и Иисуса Христа разбили наголову войска Мамая. Столь значимая победа была одержана под руководством Дмитрия Ивановича,

\footnotetext{
${ }^{1}$ Там же.

${ }^{2}$ Слово о полку Игореве и мировоззрение его эпохи. Киев, 1990. C. $35,48-49$.
}

князя Московского. И, несмотря на то, что через два года войска Тохтамыша возьмут Москву, процесс освобождения от Ордынского ига было уже не остановить.

Русские княжества сплачиваются вокруг Москвы, и начинает укрепляться национальное самосознание. Чувство единства, языкового, религиозного и исторического.

Как бы то ни было к XV веку, если и было «удельное» понимание оно изживается. Повесть стояния на Угре [1480 год]. Автор повести, в заключение пишет: «0 храбрые, мужественные сыновья русские! Потрудитесь, чтобы спасти свое Отечество...» ${ }^{3}$.

В данном случае мы видим восприятие Родины в рамках границ Московского царства.

На смену придет образ Российский Империи. Россия одержит крупные победы. Северная война (1700-1721) и Отечественная война 1812 года, а также ряддругих войн. Э. Я. Баталов в своей монографии отмечает: «Трудно реконструировать то, как обычный человек воспринимал «пафос империи», но это чувство, совершенно неведомое жителям малых стран, бесспорно, составляло часть его самоощущения» ${ }^{4}$. Понимание того, что страна огромная и многонациональная. Другие страны меньше и завидуют. Но им никогда ее не одолеть. Именно в период становления империи оказалась востребована теория - Москва третий Рим. Сформулированная еще в 1523-1524 гг. Филофеем, идоказывающая преемственность между Россией и Византией. Петром I воспринята с державныхпозиций и в качестве аргумента в территориальных претензиях.

В начале XX века, в России происходит грандиозное по своим масштабам и мировому значению событие. Великая Октябрьская Социалистическая революция сметает с исторической сцены российскую империю и старается откреститься от ее прошлого.

Формируется образ Советской России. Идея защиты первого в мире социалистического государства. «Здесь в лагере социализма - взаимное доверие и мир, национальная свобода и равенство, мирное сожительство и братское сотрудничество» ${ }^{5}, 80$-е гг. «... любви к своей ве-

\footnotetext{
${ }^{3}$ Памятники литературы Древней Руси. Вторая половина XV века / Пер. Я. С. Лурье. М., 1982. С. 514-521.

${ }^{4}$ Баталов Э. Я. Русская идея и американская мечта. М.: Прогресс-традиция, 2009. С. 25.

5 Декларация об образовании Союза Советских Социалистических Республик. Сб. документов. М., 1972. С. 379-381.
} 


\section{Духовно-нравственные искания}

ликой Советской Родине» ${ }^{1}$ Эти слова красной нитью проходят через всю историю советского государства.

Молодому советскому государству приходилось неоднократно отстаивать свою независимость. В кровавой гражданской войне большевики вышли победителями. На фронтах столкнулось несколько восприятий образа Родины. С одной стороны - это первое в мире справедливое государство рабочих и крестьян. Советская трудовая Родина. Проводники этой идеи простые рабочие, крестьяне, бывшие служащие царской армии и не только они, шли за эти идеи в бой, часто имея на своих знаменах лозунги: «За власть мозолистых рук» или смежные по смыслу. С другой стороны - это сторонники самодержавной власти, царя и веры православной. Не нужно думать, что в рядах названного в истории белого движения были сплошь офицеры и интеллигенция. На начальном этапе формирования белых армий да. Но позже ряды белого движения также пополнились крестьянами, рабочими. Были те, кто не хотел видеть никакого государства, никакой власти над собой. Но не это предмет настоящего исследования. Нам важно подчеркнуть, что произошла трагедия, образ Родины силами исторических обстоятельств был «разорван» на части. Но стоит признать, что каждая из сторон любила Родину по-своему и ни в коем случае нельзя говорить, что неправильно.

Советскому руководству потребовалось приложить огромные усилия для того, чтобы воспитать советского человека. А вместе с этим сформировать понимание образа Родины, прежде всего Советской Родины.

В Великую Отечественную войну великое чувство советского патриотизма, беспредельной любви к Родине стали решающими факторами победы над грозным и сильным противником. Ни один выпуск газеты, ни одно партсобрание не проходило без пропаганды любви к Родине, без призыва сражаться с противником не щадя своей жизни и крови ${ }^{2}$. С плакатов работы Тоидзе «Родина - Мать Зовет», звала страна своих сыновей встать на защиту Отечества.

Конечно, образ Родины проявлялся особенно ярко, и порывы чувства патриотизма усилива-

\footnotetext{
${ }^{1}$ Андропов Ю.В. Шестьдесят лет СССР. М.: Политиздат, 1982. C. 15.

${ }^{2}$ ЦАМО. Ф.33А. О. 877. Д. 17. Л. 103, 129. Ф. 208. О. 2526. Д. 101. Л. 6, 9-20, 259. Ф. 208. О. 2526. Д. 331. Л. 42, 85, 311, 314.
}

лись, при моментах в нашей истории, когда речь шла о существовании Родины. Ни одна страна мира не имеет такого права гордиться своей историей, какое право имеет Россия. Золотыми чернилами вписаны ратные подвиги наших предков в летопись нашей истории. Интересное наблюдение делает Бердяев: «В русской истории есть уже пять периодов, которые дают разные образы. Есть Россия киевская, Россия времен татарского ига, Россия московская, Россия петровская и Россия советская» ${ }^{3}$.

Возвращаясь к Первой мировой войне: «Русская национальная мысль чувствует потребность и долг разгадать загадку России, понять идею Росси, определить ее задачу и место в мире» ${ }^{4}$. Следующая мысль Бердяева будет важной для формулирования некоторых наших выводов. «... И для судьбы России самый жизненный вопрос - сумеет ли она себя дисциплинировать для культуры, сохранив все свое своеобразие, всю независимость своего духа» 5 .

На этот же момент самобытности обращал внимание И.А. Ильин, рассуждая о творчестве Пушкина: «Вот почему, утверждая русскость Пушкина, я имею в виду не гениальную обращенность его к другим народам, а самостоятельное, самобытное, положительное творчество его, которое было русским и национальным» ${ }^{6}$. И. С. Шмелев в своей работе «Лето Господне. Праздники», отмечает, что дух Руси - это дух православный. Этот дух, вера в Бога дает жизненную силу, стремление к святости. И как следствие «... победу над своими страстями, над природой и над врагами...»?

С. Франк в своей статье «Из размышлений о русской революции» говорит следующее: «Старая дворянская Россия, постепенно старевшая и умиравшая начиная со второй половины XIX века и потому постепенно отступающая перед натиском мужицкой России, ныне окончательно умерла и взамен ее созревает и слагается мужицкая Россия» ${ }^{8}$ Обращает на себя внимание образ России.

${ }^{3}$ Бердяев Н.А. Русская идея. О России и русской философской культуре. М., 1990. С. 45.

${ }^{4}$ Бердяев Н. А. Судьбы России. Репринтное воспроизведение издания 1918 года. М.: Изд-во МГУ, 1990. С. 1.

5 Там же. С. 54.

${ }^{6}$ Ильин И.А. Одинокий художник / Сост., предисл. и примеч. В. И. Белов. М.: Искусство, 1993. С. 47.

7 Там же. С. 119.

${ }^{8}$ Русская идея: В 2-х тт. Т. 2 / Сост. В. М. Пискунов; коммент. Н.Б. Злобина. М.: Искусство, 1994. С. 25. 


\section{Педагогика и просвещение 3(11) • 2013}

Павел Николаевич Милюков отмечает, что суть национального самосознания - это национальная традиция. Последняя в свою очередь является, по мнению Милюкова - передачей из поколения в поколение одних и тех же национальных стремлений ${ }^{1}$.

Н. Трубецкой рассуждая об отрицательном влиянии Монгольского Ига, упоминает понятии национальной солидарности и.т.д. И говорит о том, что: «... через двести с лишним лет Россия вышла из-под ига в виде, может быть, и «неладно скроенного», но очень «крепко сшитого» православного государства, спаянного внутренней духовной дисциплиной и единство «бытового исповедничества», проявляющего силу экспансии и воне» ${ }^{2}$. Консолидация государства под общими идеями. Для отражения внешней угрозы и сохранения своей культуры и самобытности, если можно так подытожить.

Резюмируя все вышесказанное, подведем некоторые итоги. Всю свою историю Россия вела войны, в каждом столетии и образ Родины, ассоциировался с ее защитой. Образ Родины защита - национальная идея. Менялся образ, но Родина оставалась.

Но есть и другой вид защиты. Защита своей традиционной культуры, языка, нашей Великой истории. И необходимо активизировать этот вид защиты.

Мы не имеем права рушить то, что создавалось веками, нашими предками. Если Родине будет угрожать опасность, встанем на ее защиту. Сегодня нельзя путать первый тип защиты, с оружием в руках, со вторым типом защиты культуры, самобытности. Стоит отметить, раньше враг был перед нами, будь то Швеция, Франция, фашистская Германия. А сейчас такого явного врага нет. При формировании национальной идеи все эти нюансы необходимо учитывать. Чтобы национальная идея, действительно являлась общенациональной. Идеей, которая станет связующим звеном между нашим прошлым, настоящим и будущим.

\section{Список литературы:}

1. Андропов Ю. В. Шестьдесят лет СССР. М.: Политиздат, 1982.

2. Баталов Э. Я. Русская идея и американская мечта. М.: Прогресс-традиция, 2009.

3. Бердяев Н. А. Судьбы России. Реприн тное воспроизведение издания 1918 года. М.: Изд-во МГУ, 1990.

4. Бердяев Н. А. Русская идея. О России и русской философской культуре. М., 1990.

5. Декларация об образовании Союза Советских Социалистических Республик. Сб. документов. М., 1972.

6. Ильин И. А. Одинокий художник. М.: Искусство, 1993.

7. Карамзин Н. М. История Государства Российского. В 3-х тт. Тула: Приокское издание, 1990.

8. Памятники литературы Древней Руси. XIII век. М., 1981.

9. Памятники литературы Древней Руси. Вторая половина XV века. М., 1982.

10. Русская идея. В 2-х тт. М.: Искусство, 1994.

11. Слово о полку Игореве и мировоззрение его эпохи. Киев, 1990.

12. ЦАМО. Ф. 33А. 208.

\section{References (transliteration):}

1. Andropov Yu.V. Shest'desyat let SSSR. M.: Politizdat, 1982.

2. Batalov E. Ya. Russkaya ideya i amerikanskaya mechta. M.: Progress-traditsiya, 2009.

3. Berdyaev N. A. Sud'by Rossii. Reprintnoe vosproizvedenie izdaniya 1918 goda. M.: Izd-vo MGU, 1990.

4. Berdyaev N. A. Russkaya ideya. O Rossii i russkoi filosofskoi kul'ture. M., 1990.

5. Deklaratsiya ob obrazovanii Soyuza Sovetskikh Sotsialisticheskikh Respublik. Sb. dokumentov. M., 1972.

6. Il'in I. A. Odinokii khudozhnik. M.: Iskusstvo, 1993.

7. Karamzin N. M. Istoriya Gosudarstva Rossiiskogo. V 3-kh tt. Tula: Priokskoe izdanie, 1990.

\footnotetext{
${ }^{1}$ Там же. С. 46.

2 Там же. С. 83.
} 


\section{Духовно-нравственные искания}

8. Pamyatniki literatury Drevnei Rusi. XIII vek. M., 1981.

9. Pamyatniki literatury Drevnei Rusi. Vtoraya polovina XV veka. M., 1982.

10. Russkaya ideya. V 2-kh tt. M.: Iskusstvo, 1994.

11. Slovo o polku Igoreve i mirovozzrenie ego epokhi. Kiev, 1990.

12. TsAMO. F. 33A. 208. 